\title{
38
}

\section{Social Protection for Migrant Workers in China}

\author{
Tao Liu and Tobias ten Brink
}

\section{Introduction}

When the Chinese party-state began to open up and reform its domestic economy in the 1980s, the economy was still predominantly rural. With the associated creation of special economic zones, primarily in coastal provinces, an industrialisation process began which has seen the construction of the largest urban agglomerations and industrial zones in global history. This particularly applies to the Pearl River and Yangtze River deltas with megacities such as Shenzhen, Guangzhou, Shanghai, or

T. Liu

Zhejiang University, Hangzhou, China

e-mail: tao.liu@uni-due.de

T. ten Brink $(\bowtie)$

Jacobs University Bremen, Bremen, Germany

e-mail: t.tenbrink@jacobs-university.de 
Hangzhou. One cornerstone of China's economic miracle was domestic migrant labour. Through the incremental liberalisation of domestic migration control, millions of rural residents had been allowed to move to coastal urban areas to work in low-skilled and labour-intensive sectors. One well-known example is the Taiwanese company Foxconn, currently the world's largest contract manufacturing company, which assembles cell phones and laptops for several major companies, including Apple. In its main business park, north of the city centre of Shenzhen, alone, the company had a staff of approximately 300,000 largely migrant workers in 2008 (ten Brink 2019, 138).

Today, migrant workers constitute the largest segment of the urban labour force in China. Between 2000 and 2015, their share of the urban working population increased from 36 percent to over 60 percent (Lee 2016). To understand the specific role of this huge class of domestic migrants in China's reform process, as well as the problems it encountered in trying to access some sort of social protection, we have to go back to the founding period of the People's Republic after 1949. The communist government led by Mao Zedong prescribed the joint leadership of two main classes - the working class and the peasant class - under the tutelage of the Chinese Communist Party (CCP). Although Maoist ideology attributed a leading role to workers and peasants, and the 1949 revolution received extensive backing from peasants, the CCP government in practice did not develop a pro-peasant policy. Instead of implementing policies that promoted peasant welfare, the state introduced a radical pro-industrialisation policy aimed at mobilising social, economic, and fiscal resources to promote and accelerate a catch-up industrialization at the expense of peasants' interests (Lu et al. 2001). Correspondingly, peasant welfare declined in importance. Through the "price scissors" policy (jiandaocha), the price of grains and other agricultural products were artificially reduced to a minimum and purchased by the state. These lowpriced agricultural goods made a substantial contribution to urban industrialisation and indirectly promoted the general welfare of urban residents (Knight 1995). Peasants' welfare, in contrast, was marginalised (Bian 2005).

A politically intended artificial separation of urban and rural residents was behind the Maoist industrialisation drive. Accordingly, the Chinese 
government from the late 1950s onwards adopted what was referred to as the hukou system-the household registration system prescribing that every Chinese household must be in the possession of a "family book" in which all relevant information (number of persons in the household, their names, birth dates, marriage dates, family members, and changes in the status quo) was to be accurately recorded and updated. The "family book", which is the literal translation of the Mandarin hukou, not only served as an official registration vehicle, but also was associated with a rigorous policy of exerting social and political control over populations. The two key population groups_ - urban and rural residents-were thus separated and set apart by their different hukou statuses (Cheng and Selden 1994; Chan 2009).

From its inception, the hukou system evolved into an inequalitygenerating institution, creating differential access to social and welfare facilities and programmes. Urban hukou holders were identified as members of the urban welfare system, rural hukou holders were classified as members of the rural welfare system, and serious migration restrictions were in place from the late 1950s to the 1970s (Davis 1989). This system stratified the welfare of urban and rural residents. It is also key to understanding the welfare of migrant workers during China's reform process after 1978, as well as being central to the subsequent "system of sustaining super low-cost Chinese labour in the international market" (Chan and Buckingham 2008, 604).

\section{The Social Protection of Migrant Workers: Two Phases}

\subsection{8-2002: Migrant Workers As Social Outsiders and a Disenfranchised Group}

In the process of China's reform and opening up after 1978, the development of a market economy with Chinese characteristics required a mobile labour force. To facilitate this, the domestic migration ban was gradually liberalised and ultimately lifted. That said, although the migration control function of the hukou system has diminished, the function of 
facilitating a differentiation of welfare entitlements has been consistently sustained. Through the liberalisation of domestic migration policy, since the early 1980s, more than 300 million rural residents in China were able to move to urban areas to seek jobs with higher salaries in order to achieve upward mobility. The general direction of domestic migration was from west to east and from north to south, with rural residents from the poor hinterland tending to move towards coastal provinces, the economically dynamic and prosperous regions of China (Chan and Zhang 1996; Cheng and Selden 1994).

These mass dislocations are closely connected with the hukou system and are thus different from rural-urban movements in other countries such as India or in African countries since population movements there are not constrained by a formal household registration system. The process saw agricultural hukou holders move to new locations to live alongside non-agricultural hukou holders, that is, urban residents. However, unless migrant workers are granted urban bukou and become formally registered as urban residents, they will permanently retain the status of the "other", temporarily residing in cities and not included in the institutional regulatory framework of urban areas due to their disadvantaged bukou status. ${ }^{1}$ This created a precarious situation for migrant workers' social security in reformed China. On the one hand, domestic migrants were disembedded from their home and family environment; on the other hand, they were excluded from the urban legal and institutional framework, and were additionally disembedded from the urban education system, public health, and welfare sector. This dual disembeddedness is key to understanding social protection for migrant workers. Since economic reform, Chinese migrant workers have typically taken on what have been dubbed "3D jobs" - dirty, dangerous, and demeaningwith less security and less stable wages (Sun 2019) and yet they are

\footnotetext{
${ }^{1}$ In order to promote urbanisation in China, different local urban governments have adopted policies that enable some residents with agricultural hukou to obtain non-agricultural status if certain conditions have been satisfied, for instance, the possession of certificates of higher education and a record of having worked in urban areas for several years. On these and other attempts to reform the hukou system, see Sun (2019) and Wu and Zhang (2018).
} 
the lynchpin of the extraordinary construction booms and rapid urban development in Chinese cities. Despite their crucial contribution to China's economy, they were completely excluded from urban welfare and social protection programmes in the initial reform period, and thus remained a highly vulnerable group in economic and social terms (Chan et al. 1999; Sun and Liu 2014).

In the first reform period (1978-2002), migrant workers were not only inadequately protected, they were virtually excluded from any kind of social protection programmes for the following reasons. First, migrant workers were, by definition and based on hukou status, rural residents, and their othering in urban spaces made them disenfranchised in a sociopolitical sense. Concurrently, rural social welfare in the People's Republic had rapidly deteriorated, even disintegrated entirely, since the social and financial basis for the rural collective economy and rural collective welfare- the People's Communes - had collapsed over the course of the market-oriented reforms. Due to the sudden demise of rural collectives, existing rural welfare systems such as rural cooperative medical services stepped off the stage of history (Duckett 2011). The single rural welfare system - the "Five Guarantees", which granted food, clothing, medical services, housing, and subsidies for the funerals of farmers without supporting family members-only existed in rudimentary form in some wealthy coastal areas; in many parts of the country, this programme had ceased to exist due to the fiscal drain on local villages.

Second, and more importantly, migrant workers were almost completely precluded from participating in urban social protection programmes. They were not covered by either old or new urban social welfare programmes. In the 1990s, the newly piloted and then established pension insurance, health insurance, and unemployment insurance for urban employees, and the Minimum Living Standard Scheme (dibao) for urban residents did not cover migrant workers. In sum, for the first twenty years of Chinese economic reform, migrant workers were disenfranchised outsiders in urban areas. 


\subsection{The 2000s and Beyond: Migrant Workers As an "Amphibious" Group}

Since the turn of the millennium, under pressure from international debates on decent living standards and a national upsurge in migrant worker protests, and against the backdrop of sustained double-digit growth rates, which also increased the demand for higher skills, the partystate changed course (Lee 2016). Particularly after the Hu-Wen government came to power, it corrected the previous neoliberal-looking course, and adopted a so-called "pro-people policy" (qinmin zhengce). The general welfare of Chinese residents, and especially the well-being of vulnerable citizens, was increasingly taken into consideration. Social policy in China was subject to extensive reforms, moving in particular towards greater inclusion in social protection programmes (Liu and Sun 2016a, b). A threefold transition took place:

First, since the 2000s, various new types of basic social protection programmes have been piloted and then implemented, with an emphasis on integrating uninsured residents in both urban and rural areas. A New Rural Cooperative Medical System was piloted and then rolled out nationally between 2004 and 2008. The aim was to include all Chinese farmers in a special health insurance programme based on a mixedfinancing comprising payments by peasants and subsidies from villages and different levels of government (Müller 2016). It had officially reached a coverage level of 99 percent of the rural population by 2013. Additionally, a special health insurance programme for urban residents based on a cofinancing model was established in the same period. In the field of pensions, a non-contributory basic pension for rural residents was piloted in 2009 and then launched as a national-level social protection programme in 2011, financed by tax revenues from different levels of government. This basic pension programme was supplemented by pension insurance for rural residents based on individual accounts subsidised by governments (Liu and Sun 2016a). This scheme was emulated in urban areas, where pension insurance for urban residents was created in 2011. Basic social pensions for rural and urban residents were then merged into one programme in 2014, comprising rudimentary pension security for urban and rural residents. Moreover, a work accident insurance programme for 
employees in enterprises, adapted from the German model of statutory work accident insurance, was launched in 2004 (Leisering and Liu 2010).

Second, some of the already existing urban programmes were extended to rural areas, including the urban social assistance programme (dibao), which was launched in 2007 (Liu and Sun 2016b). Further, the social relief programme (the "Five Guarantees") that had been largely abandoned has been restored and promoted in many rural areas (Liu 2014). Both programmes have contributed to establishing a basic social assistance network in rural China in which migrant workers can participate.

Third, some migrant workers in cities have been gradually included into the contribution-based and more comprehensive social insurance programmes for urban employees. Table 38.1 shows that in 2017, 62.02 million migrant workers participated in the urban pension insurance programme for employees, 62.25 million migrant workers obtained urban health insurance for employees, 48.97 million migrant workers were covered by unemployment insurance, and 78.07 million migrant workers were included in the work accident insurance programme. The proportion of migrant workers in these social insurance programmes ranged from 17 to 27 percent (see Table 38.1).

Table 38.1 Participation in urban social insurance programmes (2017)

\begin{tabular}{|c|c|c|c|c|}
\hline $\begin{array}{l}\text { Social insurance } \\
\text { programmes }\end{array}$ & $\begin{array}{l}\text { Number of } \\
\text { participants } \\
\text { (urban } \\
\text { employees) } \\
\text { (million) }\end{array}$ & $\begin{array}{l}\text { Proportion } \\
\text { of urban } \\
\text { employees } \\
(\%)\end{array}$ & $\begin{array}{l}\text { Number of } \\
\text { participating } \\
\text { migrant } \\
\text { workers } \\
\text { (million) }\end{array}$ & $\begin{array}{l}\text { Proportion } \\
\text { of migrant } \\
\text { workers (\%) }\end{array}$ \\
\hline $\begin{array}{l}\text { Pension insurance for } \\
\text { urban employees }\end{array}$ & 292.68 & 69 & 62.02 & 22 \\
\hline $\begin{array}{l}\text { Health insurance for } \\
\text { urban employees }\end{array}$ & 222.88 & 52 & 62.25 & 22 \\
\hline $\begin{array}{l}\text { Unemployment } \\
\text { insurance }\end{array}$ & 187.84 & 44 & 48.97 & 17 \\
\hline $\begin{array}{l}\text { Work accident } \\
\text { insurance }\end{array}$ & 227.24 & 54 & 78.07 & 27 \\
\hline
\end{tabular}

Source: ILO. 2019. Improve China's floating population insurance system. https:// www.ilo.org/beijing/information-resources/public-information/factsheets/ WCMS_732200/lang\%2D\%2Dzh/index.htm 
Of course, the integration of domestic migrants into the more generous, contribution-based urban insurances for employees is dependent on them finding a job with a long-term written contract. This represents a considerable challenge despite recent changes in legislation since the late 2000s, aimed at formalising labour relations and professionalising social security. For migrant workers, the employment relationship is still frequently based on a verbal agreement, since employers try to subvert or bend labour laws for instance. According to the results of a survey conducted by the National Bureau of Statistics of China, in 2014, this was the case for over half of all migrant workers (Lee 2016, 320; for a broader overview on changes in China's labour relations, see ten Brink 2019, Chap. 3). Moreover, migrant workers have problems accessing rural social protection since they are geographically separated from it. Migrants insured in the rural health insurance are often expected to seek treatment at the hospital in their place of origin, for instance, rather than going directly to a hospital in the city where they are working (Müller 2016). Services such as social assistance can often be claimed and received only at the place of registration, which means that in reality entitlements are often used as a fallback option upon return.

Compared to the previous reform period, migrant workers now have more options for inclusion in social protection programmes. The popular belief that Chinese migrant workers are completely excluded from welfare arrangements is thus outdated. Instead, we could argue that in view of the significant changes in labour relations, which, as in other capitalist modernisation processes brought extensive commodification and precarisation in their wake, the safeguarding of social integration, and thus social peace, was so far being met with relative success, not least through the basic inclusion of migrants in social security programmes (for similarities and differences with respect to the realm of labour relations and collective bargaining, see Lee [2016]; ten Brink [2019]).

Furthermore, in the second period of China's reform, the social protection and welfare of migrant workers has become more diversified and, thus, more complicated. Overall, the lives of migrant workers exhibit dual characteristics, shaped as they are by both urban and rural institutions, a phenomenon which in China is referred to as "social amphibiousness". Therefore, today's migrant workers often opt to participate in either 
rural or urban programmes or even combine both-provided they have a secure job with a long-term contract. Thus, the problem of overlapping insurance has arisen, particularly in the area of health insurance. Since migrant workers may possess a "double status" of rural residents and urban employees, it is possible that some of them are intentionally or unintentionally covered by two social protection programmes. For instance, a 2014 report from the Peoples' Network claimed that there are more than 100 million cases of overlapping insurances in China. The typical case is where a rural resident who was previously insured in the New Rural Cooperative Medical System moves to an urban area, is employed by one enterprise, and consequently also participates in (the more generous) medical insurance for urban employees. The Ministry of Human Resources and Social Security has not provided information about the precise number of individuals with overlapping health insurance; however, this phenomenon is widespread in Chinese society, making it a contentious topic.

\section{Conclusion}

China's opening up to the world economy has dramatically changed the lives of those who moved to urban centres in search of work and social mobility. This chapter has elaborated the two phases of development of social protection for migrant workers. During the first period of economic reform, migrant workers were precluded from participating in the urban welfare sector, and were highly inadequately protected by a rudimentary rural welfare system. Since the dawn of the new millennium, migrant workers have evolved into an "amphibious" group, increasingly protected by an emerging basic rural social protection system, and, at the same time, at least partially incorporated into urban social insurance programmes.

However, despite the expansion of basic social protection for Chinese migrant workers triggered by a combination of international and national factors, this cannot disguise the fact that they still constitute a highly vulnerable group. For example, if migrant workers are only insured by rural health insurance, they usually have to pay the costs of medical 
treatment in cities out of pocket, and are reimbursed only later after migrating back to their home villages. This delayed reimbursement has increased suffering among migrant workers. For those who only temporarily entered into urban pension insurance programmes for employees and then returned to the system of rural pension insurance, transferring the accrued pension entitlements between different systems and different provinces represents a conundrum. Finally, considering that migrant workers are disproportionately employed in dangerous and risky sectors, and less than 30 percent are insured by work accident insurance, they remain a socially vulnerable and disadvantaged group, despite the limited positive changes in the last two decades.

Acknowledgements This chapter is a product of the research conducted in the Collaborative Research Center "Global Dynamics of Social Policy" at the University of Bremen. The centre is funded by the Deutsche Forschungsgemeinschaft (DFG, German Research Foundation)—project number 374666841-SFB 1342.

\section{References}

Bian, Morris L. 2005. The Making of the State Enterprise System in Modern China: The Dynamics of Institutional Change. Cambridge: Harvard University Press. Chan, Kam Wing. 2009. The Chinese Hukou System at Fifty. Eurasian Geography and Economics 50 (2): 197-221.

Chan, Kam Wing, and Will Buckingham. 2008. Is China Abolishing the Hukou System? China Quarterly 195: 582-606.

Chan, Kam Wing, and Li Zhang. 1996. The Hukou System and Rural-Urban Migration in China: Processes and Changes. Chinese Sociology \& Anthropology 29 (1): 15-26.

Chan, Kam Wing, Ta Liu, and Yunyan Yang. 1999. Hukou and Non-Hukou Migrations in China: Comparisons and Contrasts. International Journal of Population Geography 5 (6): 425-448.

Cheng, Tiejun, and Mark Selden. 1994. The Origins and Social Consequences of China's Hukou System. The China Quarterly 139: 644-668.

Davis, Deborah. 1989. Chinese Social Welfare: Policies and Outcomes. The China Quarterly 119: 577-597. 
Duckett, Jane. 2011. Challenging the Economic Reform Paradigm: Policy and Politics in the early 1980s' Collapse of the Rural Co-Operative Medical System. The China Quarterly 205: 80-95.

Knight, John. 1995. Price Scissors and Intersectoral Resource Transfers: Who Paid for Industrialization in China? Oxford Economic Papers 47 (1): 117-135.

Lee, Ching Kwan. 2016. Precarization or Empowerment? Reflections on Recent Labor Unrest in China. Journal of Asian Studies 75 (2): 317-333.

Leisering, Lutz, and Tao Liu. 2010. Globale Wissensdiffusion in der Sozialpolitik. Zeitschrift für Sozialreform 56 (2): 173-206.

Liu, Tao. 2014. Intellectual Origins of the Chinese Minimum Living Standard System. Applying a Model of Multiple Knowledge Diffusion. FLOOR Working Paper 21: 1-45.

Liu, Tao, and Li Sun. 2016a. Pension Reform in China. Journal of Aging \& Social Policy 28 (1): 15-28.

- 2016b. Urban Social Assistance in China: Transnational Diffusion and National Interpretation. Journal of Current Chinese Affairs 45 (2): 29-51.

Lu, Qi, Jin-yan Zhan, and Kang-won Lee. 2001. An Overview on the UrbanRural Interaction in the Past Fifty Years in China. Chinese Geographical Science 11 (3): 193-200.

Müller, Armin. 2016. Hukou and Health Insurance Coverage for Migrant Workers. Journal of Current Chinese Affairs 45 (2): 53-82.

Sun, Li. 2019. Rural Urban Migration and Policy Intervention in China. Migrant Workers' Coping Strategies. London: Palgrave Macmillan.

Sun, Li, and Tao Liu. 2014. Injured but not Entitled to Legal Insurance Compensation-Ornamental Institutions and Migrant Workers' Informal Channels in China. Social Policy \& Administration 48 (7): 905-922.

ten Brink, Tobias. 2019. China's Capitalism. A Paradoxical Route to Economic Prosperity. Philadelphia: University of Pennsylvania Press.

Wu, Lili, and Wei Zhang. 2018. Rural migrants' Homeownership in Chinese Urban Destinations: Do Institutional Arrangements Still Matter after Hukou Reform? Cities 79: 151-158. 
Open Access This chapter is licensed under the terms of the Creative Commons Attribution 4.0 International License (http://creativecommons.org/licenses/ by/4.0/), which permits use, sharing, adaptation, distribution and reproduction in any medium or format, as long as you give appropriate credit to the original author(s) and the source, provide a link to the Creative Commons licence and indicate if changes were made.

The images or other third party material in this chapter are included in the chapter's Creative Commons licence, unless indicated otherwise in a credit line to the material. If material is not included in the chapter's Creative Commons licence and your intended use is not permitted by statutory regulation or exceeds the permitted use, you will need to obtain permission directly from the copyright holder.

(c) (i) 